\title{
UK discussed ban on foreign job ads in 1960s
}

London

The British government was so worried about the loss of scientists and engineers to the United States in the late 1960s that it considered banning foreign recruitment advertising, according to documents released last week by the Public Record Office.

The documents, released under the 'thirty-year rule', also reveal proposals from a top civil servant in the Cabinet Office that scientists should be explicitly treated as an elite group in society, with benefits including special tax exemptions.

But reports from Germany, suffering a similar 'brain drain', showed that advertising bans had had little effect. The government was also worried that the press would react with hostility to such a suggestion.

Civil servants expected the Labour government of the time to be strongly opposed to making scientists a social elite. Even a merit award system for young scientists was scotched by the minister for education and science, Edward Short, as neither desirable nor necessary. Short warned that it could be a source of discontent and "future trouble" as it had been in the medical profession.

Officials at the time had difficulty in accurately assessing the extent of the 'brain drain'. Estimates of graduate emigration ranged from as little as 5 per cent to as much as 40 per cent in at least one university that was a producer of top-quality engineers.

In 1967 the United Kingdom had a net loss of about 2,300 active scientists and 3,600 engineers. There was evidence that people leaving the country were disproportionately well qualified.

Prime Minister Harold Wilson wrote to the minister for employment and productivity, Barbara Castle, stressing his concern at estimates that the United States would have a shortfall of about 400,000 engineers in the following decade, offering even more job opportunities to British graduates.

Cabinet Office officials considered the matter so important that they raised the possibility with the government's chief scientific adviser, zoologist Sir Solly Zuckerman, of treating scientists as "a preferred class of citizens". This could have involved preferential grants, reduced taxation and improved arrangements for professional mobility and pensions.

"Any proposals based on such conclusions would be politically impossible at present but if the statement [that it is vital to stop the brain drain] is correct, I believe we should face it honestly," says a letter to Zuckerman from F. H. Allen of the Cabinet Office. "There have been elite classes in the past: perhaps we shall deliberately have to create another in the future."

Zuckerman thought that improved uni-

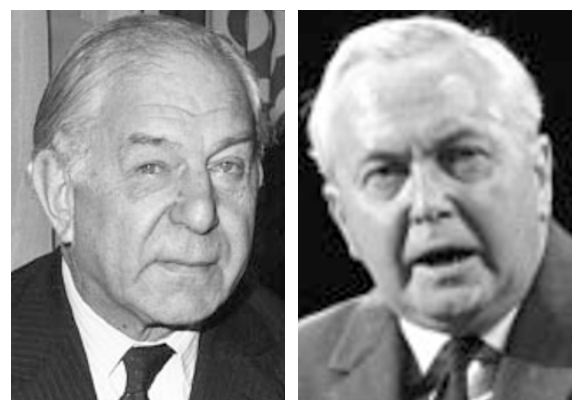

Zuckerman (left) and Wilson: concerned at the lure of the United States for UK scientists.

versity administration would help, and advised vice-chancellors and principals to encourage moves towards a system like that of the United States. There, staff members were encouraged to accept external

consulting work and had flexibility in salary systems and in making research grant applications.

A document from the Ministry of Technology to the Cabinet Office suggests the reaction to a possible advertising ban was reflected in the stout defence by the science magazine New Scientist in the face of "an outcry" by readers to its acceptance of fullpage advertisements from an American recruiting agency. The authors of the ministry paper point out that the magazine "stood firm on its right to inform scientists in this country of the opportunities elsewhere".

Zuckerman also advised the Foreign and Commonwealth Office to "limit" help requested by the Canadian government for Canadian firms trying to recruit British staff.

Natasha Loder

\section{Bell Labs win superconductivity patent}

\section{Washington}

Bell Laboratories, the research arm of New Jersey-based Lucent Technologies, has won a fierce competition for the US patent rights to yttrium barium copper oxide (YBCO). One of the most important hightemperature superconductor materials, this was identified by several rival groups of researchers in early 1987.

After twelve years of deliberation, a panel of four patent judges has ruled that Bell Labs can exercise the patents it filed on 3 March 1987, when at least four research groups in the United States were racing to discover oxide materials that would attain superconductivity at relatively high temperatures.

The race had been set off the previous year when Alex Müller and Georg Bednorz, two researchers at IBM research laboratories at Rüschlikon, Switzerland, discovered a copper oxide ceramic that could conduct electricity without resistance at a temperature of 35 Kelvin. Researchers then urgently looked for ceramics that would show the same property at more than 77 Kelvin - the temperature of liquid nitrogen, a cheap coolant that would allow widespread application of the materials.

Teams at IBM, the Naval Research Laboratory and the University of Houston filed patents for the successful compound soon after Bell Labs, which was then part of AT\&T. Under US patent law, they were able to pursue an 'interference' procedure to establish which team had actually discovered the compound first, and was therefore entitled to patent it.

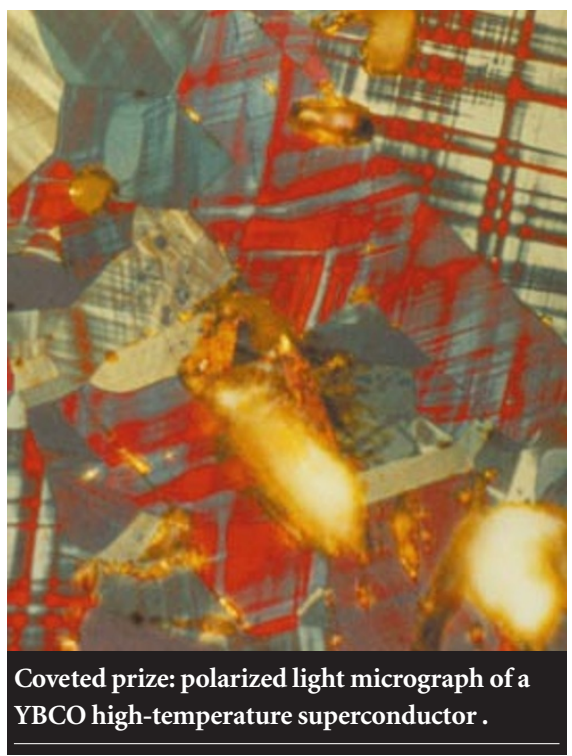

The finding of the US Patent and Trademark Office has not yet been publicly announced, but has been welcomed by scientists at Bell Labs. "The process has shown that we were the first to do it," says Bertram Batlogg, one of the team that made the discovery.

But some of their rivals continue to dispute that, claiming that Bell's rivals were merely unable to prove that they had made the discovery ahead of the filing date. "It was a tie, but they got the patent because they filed first," says one ex-IBM scientist who has followed the dispute closely.

The scientist also contends that the Bell Labs team "had no data" to prove that it actually had a material that was superconducting above 70 Kelvin 
throughout 90 per cent of its volume - the criterion the patent office said was needed to prove the value of the discovery. He contends that Bell's X-ray diffraction data, showing the crystalline structure of their material, were insufficient to prove 90 per cent bulk superconductivity.

Batlogg dismisses the distinction.

"There's been a misunderstanding about us not having the data," he says. "The X-ray diffraction data showed that we had a single crystal phase, and the magnetic and transport data showed that we had a superconductor. I'm surprised people are still so worked up about this."

Lucent has asked BTG, the UK-based technology licensing company, to sell licensing rights to other parties. One such agreement has already been reached with American Superconductor, a corporation based in Westborough, Massachusetts. Patents have also been issued to Bell Labs for YBCO superconductors in Europe since 1996, and in Japan earlier this year, but IBM also has patents in these countries for technology used to fabricate the materials.

It is not clear if IBM will appeal against the patent office's ruling.

Colin Macilwain

\section{Genetics takes off in Naples as institute moves south}

\section{Milan}

A major Italian genetic research institute will move south from Milan to Naples this summer, enhancing the city's reputation as one of the country's leading areas for genetic research and reversing the usual direction of scientific migration in Italy.

The relocation of the Telethon Institute of Genetics and Medicine (TIGEM) has been made possible with regional development funds from a variety of sources. These are intended to promote research and development in Italy's poorer southern regions.

TIGEM will move into an Integrated Centre for Biological Research that is being set up by the CNR, Italy's research council. The centre will also house the CNR's International Institute of Genetics and Biophysics (IIGB), best known for its pioneering work on bacterial phage genetics, and several smaller biological research institutes.

A further boost to Naples' reputation in genetics could come from a second initiative, also supported by development funds. Called Biogem, this 40 billion lire (US\$200 million) fund is intended to expand work on developmental biology, human genetics and cancer in Naples and its environs. Although approved in principle by the research ministry in 1997, the money is not expected to start flowing until spring this year.

The IIGB will be a focus for genetics in Naples. The centre will be located near Naples' major research hospitals and the Federico II University, in laboratories that were vacated by a pharmaceutical company in the mid-1970s and acquired by the CNR in 1996. European Union structural funds for underdeveloped regions have paid for refurbishing the building.

TIGEM was set up in 1994 by Telethon, a charity that raises money for research into genetic diseases through an annual television appeal. The organization's premises in

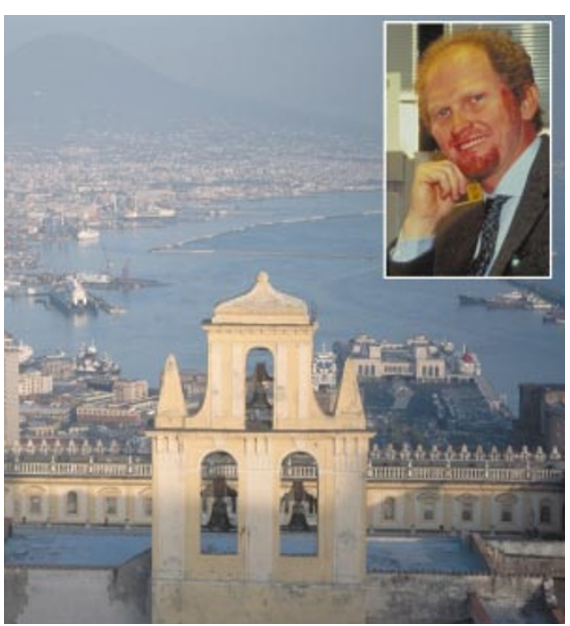

Promising outlook: Naples has the funds for two new research centres. Inset, Andrea Ballabio.

the San Raffaele Biomedical Science Park in Milan had become cramped, and last year it began looking for new premises for its staff of 75 , including 40 scientists.

The CNR centre offers much more space and other scientific and financial incentives, says director Andrea Ballabio, himself a Neapolitan. Under an agreement with the research ministry, the CNR will give TIGEM laboratory space in its new centre rent-free, while the 5 billion lire costs of the move are coming out of ministry funds allocated to support research in the south.

The Campagna region, in which Naples lies, will provide further funding for running TIGEM during its first three years in Naples. Telethon, which will continue to provide TIGEM's annual 4.3 billion lire running costs, does not intend to increase the number of Telethon staff, despite the extra space available. "We hope to have space to host scientists from other research institutions such as CNR or the universities," says Ballabio.

TIGEM scientists already work closely

ฝึ 2000 Macmillan Magazines Ltd with scientists in Naples, which has Italy's second-highest concentration of human geneticists after Milan. Such collaborations resulted in 1997 in the identification of the genes for spastic paraplegia, and, last year, for lysinuric protein intolerance - a rare disorder causing growth delay and sometimes mental retardation. Future work will attempt to identify genes involved in retinal disorders, among others. When TIGEM and the IIGB merge their gene-sequencing facilities, Naples will probably have the largest sequencing capacity in Italy, says IIGB director John Guardiola.

Guardiola wants to work with TIGEM scientists on screening the genetically homogeneous populations of local villages, where intermarriage is common, to try to identify carriers of rare genetic diseases.

Modern Italian genetics began in Naples. Adriano Buzzati Traverso was the IIGB's founding director in 1962, and Luigi Luca Cavalli-Sforza was director in the mid1960s. It was there that the first gene on the X chromosome was identified in 1981. The university also has a strong genetics programme.

Because not all TIGEM scientists will make the move, the prospect of vacancies for prestigious Telethon positions is delighting local geneticists. Guardiola says that many geneticists who trained in Naples and subsequently left have already expressed interest in applying for the jobs. "It is an opportunity to come home to an even stronger scientific environment than the one they left - and with the most modern facilities," he says.

Ballabio hopes that TIGEM researchers will benefit from the Biogem initiative. Half of Biogem's grant will support projects in developmental biology, human genetics and cancer, and the expansion of research services, including bioinformatics, sequencing and the development of mouse models of disease, in various research institutions.

Roberto Di Lauro, a professor of human genetics at the Federico II University of Naples, and secretary of Biogem's scientific and technological council, says that Telethon and Biogem intend to work closely together to avoid duplicating efforts.

Thus, sequencing will only be done at the new CNR centre, he says. Genomics mostly the development of mouse models of human diseases - will be expanded at an institute to be built with the remaining 20 billion lire of Biogem money at Ariano Irpino. This small town, in the mountains some 100 kilometres from Naples, is the home town of research minister Ortensio Zecchino.

The remote location of this research institute has been criticized by many Italian scientists. But Di Lauro counters that "no one in Naples came forward with a site in the city", and that "while critical mass is important, it is also important to let research start up in new locations".

Alison Abbott 